\title{
Immunoglobulins in tears of normal Indian people
}

\author{
D. K. SEN, G. S. SARIN, K. MANI, AND KUNAL SAHA* \\ From the Departments of Ophthalmology and Bacteriology*, Maulana Azad Medical College \\ and Associated Irwin and G.B. Pant Hospitals, New Delhi, India
}

The presence of immunoglobulin-containing plasma cells in the various epithelial tissues of the body suggests a distinct secretory immunological system (Tomasi and Bienenstock, 1968). Immunoglobulins are found in body secretions. They may be important local agents of the host defence mechanism in initial or recurrent bacterial, viral, or other infectious processes (Little, Centifanto, and Kaufman, 1969). IgA is the dominant immunoglobulin among external secretions but smaller amounts of IgG and IgM may be present (Chodirker and Tomasi, r 963; Little and others, 1969; Kühl and Albrecht v. Graefes, I97 I; Brauninger and Centifanto, 1971; McClellan, Whitney, Newman, and Allansmith, 1973).

Tears continuously bathe the cornea and conjunctiva. A change in their composition may be associated with local pathological changes (Josephson and Weiner, 1968). The conjunctiva and associated lacrimal glands, like all other mucosal tissues which are exposed to the environment, have substantial collections of lymphoid elements (Knoph, Blaklow, Glassman, Cline, and Wong, I97I). These synthesize immunoglobulins which are secreted into the tears. However, the immunoglobulin levels in tears have not been so extensively studied as certain other external secretions. The few reports available are conflicting. The present study was undertaken primarily to determine the immunoglobulin levels in the tears of normal Indian people and to compare them with those reported in Western people.

\section{Subjects and methods}

Tears were collected from 50 persons without any ocular or systemic disease. The eyes and ocular adnexa were carefully examined under magnification with a slit lamp and the fundus was examined by one of us (DKS) with both direct and indirect ophthalmoscopy after full dilatation of the pupil. The systemic examinations were carried out by a senior resident (KM). Only people who were normal in all respects were included in the study. They were mostly adults al-

Address for reprints: Dr D. K. Sen, Department of Ophthalmology, Maulana Azad Medical College and Associated Irwin and G.B. Pant Hospitals, New Delhi-I 10002, India though the age range was 14 to 50 years (mean $30 \cdot 1$ years). There were 37 males and 13 females.

The subjects were asked to stare at a strong light from a slit lamp for some time. When tears had collected in the lower cul-de-sac they were drawn into a micropipette by capillary action. Care was taken not to damage the conjunctiva. The tears were expressed from the pipette into small screw-capped vials. The samples in each case were collected from both eyes and pooled; the volume ranged from 100 to $200 \mu \mathrm{l}$. The pooled samples were stored at $-4^{\circ} \mathrm{C}$ until needed.

The $\operatorname{IgA}, \operatorname{IgD}, \operatorname{IgG}$, and $\operatorname{IgM}$ in the samples were measured by a single radial immunodiffusion method (Mancini, Carbonera, and Heremans, 1965) using monospecific goat antisera against heavy-chain human $\operatorname{IgA}, \operatorname{IgD}, \operatorname{IgG}$, and $\operatorname{IgM}$, and the reference standards of $\operatorname{IgD}, \operatorname{IgG}$, and IgM were obtained from Meloy Laboratories, Virginia, USA. The reference standard of secretory IgA, prepared from human colostrum, was kindly donated by $\mathrm{Dr}$ R. Thompson, Birmingham, England.

\section{Results}

IgA was invariably found in all the samples. The mean level was $24 \cdot 6 \pm \mathrm{i} 4 \cdot 8 \mathrm{mg} / \mathrm{r}$ oo $\mathrm{ml}$. There was no significant difference statistically $(\mathrm{P}<0.6)$ between tear IgA level in males $(23.6 \pm 15.9 \mathrm{mg} /$ $100 \mathrm{ml})$ and that in females $(26.4 \pm 14.3 \mathrm{mg} / 100$ $\mathrm{ml}$ ), although the levels in females tended to be higher (Fig. I). The distribution of IgA level in different age groups is shown in Fig. 2. IgA levels in the age groups were: 10 to 20 years, $28 \cdot 6 \pm 9 \cdot 8$ $\mathrm{mg} / \mathrm{I} 00 \mathrm{ml} ; 2$ I to 30 years, $28 \cdot 0 \pm 27 \cdot 2 \mathrm{mg} / 100 \mathrm{ml}$; $3^{1}$ to 40 years, $19.5 \pm 10.4 \mathrm{mg} / \mathrm{ro0} \mathrm{ml}$; and 41 to 50 years, $20 \cdot 7 \pm 7 \cdot 1 \mathrm{mg} / 100 \mathrm{ml}$. The difference between the tear IgA levels in the various age groups was not significant.

IgD was not found in any of the samples. IgG was very low in most, being less than $1 \mathrm{mg} / \mathrm{I00} \mathrm{ml}$ in 42 and absent in the remaining 8. IgM was absent except in one sample, in which it was less than $\mathrm{I} \mathrm{mg} / \mathrm{r} 00 \mathrm{ml}$.

\section{Discussion}

IgA was the predominant immunoglobulin in the normal human tears we studied. Most other authors 
have found the same (Table) except Bazzi, Cattaneo, Migone, and Farina (1970), who found IgG to be predominant, and McClellan and others (1973), who found the levels of $\operatorname{IgA}$ and IgG to be almost equal.

The IgA level in our study is comparable to the findings of other authors except Chodirker and Tomasi (1963). Statistical analysis of IgA levels in different age groups shows that the IgA level tends to be higher in younger than in older people, whereas in serum it is significantly higher in older people (Schwick and Becker, 1969). The level of IgA in tears in our study is also comparable with that reported in other body secretions. In jejunal

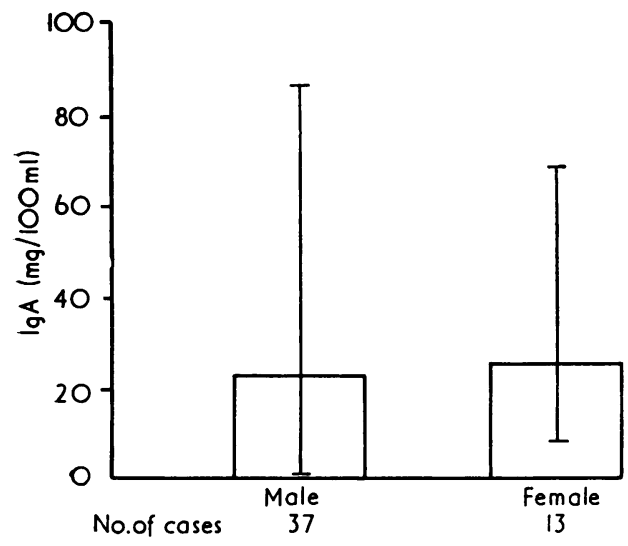

FIG. I Sex distribution of IgA in tears (mean and range)

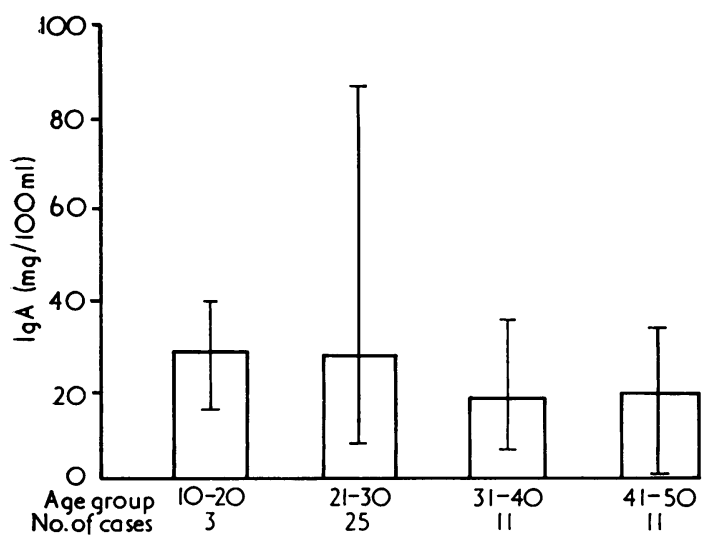

FIG. 2 Ig $A$ in tears in different age groups (mean and range)
Table Reported levels ( $\mathrm{mg} / \mathrm{1} 00 \mathrm{ml}$ ) of immunoglobulin in tears of normal subjects

\begin{tabular}{|c|c|c|c|c|c|c|}
\hline Author & Year & $\begin{array}{l}\text { No. of } \\
\text { subjects }\end{array}$ & $\operatorname{Ig} A$ & $\operatorname{Ig} D$ & $I g G$ & $\operatorname{Ig} M$ \\
\hline \multirow{2}{*}{\multicolumn{7}{|c|}{$\begin{array}{ll}\text { Chodirker and } & \\
\text { Tomasi } & 1963 \\
\text { Bracciolini (after } & \\
\text { onion vapour } & \\
\text { stimulation) } & 1968\end{array}$}} \\
\hline & & & & & & \\
\hline Barnett & I 968 & 6 & 31 & NS & 3 & I \\
\hline $\begin{array}{c}\text { Little, Centifanto, } \\
\text { and Kaufman }\end{array}$ & 1969 & 10 & 21 & NS & $\operatorname{Tr}$ & NS \\
\hline $\begin{array}{l}\text { Bazzi, Cattaneo, } \\
\text { Migone, and } \\
\text { Farina }\end{array}$ & 1970 & 9 & 23 & NS & 79 & 一 \\
\hline $\begin{array}{l}\text { Brauninger and } \\
\text { Centifanto }\end{array}$ & 1971 & 24 & $9-50$ & NS & NS & NS \\
\hline $\begin{array}{l}\text { McClellan, } \\
\text { Whitney, } \\
\text { Newman, and }\end{array}$ & & & & & & \\
\hline $\begin{array}{c}\text { Allansmith } \\
\text { Present study }\end{array}$ & 1973 & 74 & 17 & 二 & $\begin{array}{l}14 \\
\mathrm{Tr}^{*}\end{array}$ & $\overrightarrow{+}$ \\
\hline Present study & 1975 & 50 & & & & \\
\hline
\end{tabular}

NS $=$ not studied. $\mathrm{Tr}=$ trace

* < I mg/100 ml in 42 samples studied

$\dagger<1 \mathrm{mg} / 100 \mathrm{ml}$ present in one subject

juice it is $2 \mathrm{r} \cdot 2 \mathrm{mg} / \mathrm{r} 00 \mathrm{ml}$ (Douglas, Crabbe, and Hobbs, 1970); in saliva $19.4 \mathrm{mg} / 100 \mathrm{ml}$ (Brandtzesg, 197I); and in bronchial secretion $23.6 \mathrm{mg} / 100 \mathrm{ml}$ (Deuschl and Johansson, 1974).

The only other report on IgD levels available to us is that of McClellan and others (1973), and they also noted it to be absent. IgG was present in very low concentrations in our series, which is in agreement with Chodirker and Tomasi (r963), Bracciolini (r968), and Little and others (1969). However, McClellan and others (1973) found it to be $14 \mathrm{mg} / \mathrm{roo} \mathrm{ml}$, and Bazzi and others (1970) found it to be as high as $79 \mathrm{mg} / \mathrm{r} 00 \mathrm{ml}$. We also failed to detect $\operatorname{IgM}$ in our samples. This agrees with Bracciolini (1968), Bazzi and others (1970), and McClellan and others (1973). Barnett ( 1968 ), however, reported an IgM level of $\mathrm{I} \mathrm{mg} / \mathrm{s} 00$ $\mathrm{ml}$ in normal tears.

\section{Summary}

Immunoglobulin concentrations in tears from 50 healthy Indians aged from 14 to 50 years were measured by a standard immunodiffusion method. The levels of IgA were substantial; those of IgG were very low; and $\operatorname{IgD}$ and IgM were not present. The mean IgA level was $24.6 \mathrm{mg} / 100 \mathrm{ml}$.

We thank Dr K. B. Puri, junior resident in ophthalmology, for his help in collecting the tears.

\section{References}

BARNETT, e. v. (1968) F. Immunol., roo, I093

Bazzi, c., Cattaneo, R., Migone, v., and farina, m. (1970) Prog. Immunobiol. Stand., 4, 333

BRacciolini, M. R. (1968) Ann. Ottal., 94, 490 
BRANDTZESG, P. (1971) Clin. exp. Immunol., 9, 69

Brauninger, G. E., and CENTIFANTo, y. M. (1971) Amer. F. Ophthal., 72, 558

CHODIRKER, W. B., and TOMASI, T. B. JR. (1963) Science, 142, 1080

DEUSCHL, H., and JOHANSSON, s. G. o. (1974) Clin. exp. Immunol., 16, 401

DOUGLAS, P. A., CRABBE, P. A., and hOBBS, J. R. (1970) Gastroenterology, 59, 4I 5

, and WEINER, R. S. (1968) F. Immunol. 100, 1080

KÜHL, W., and ALBRECHT v. GRAEFES (197I) Arch. klin. exp. Ophthal., 72, 558

KNOPH, H., BLAKLOW, N., GLASSMAN, M., CLINE, w., and WONG, v. (1971) Invest. Ophthal., ro, 760

little, J. M., Centifanto, Y., and kaufman, H. E. (i969) Amer. J. Ophthal., 68, 898

MANCINI, G., CARBONERA, A., and HEREMANS, J. (1965) Immunochemistry, 2, 235

MCCLELlan, B. H., WhitNey, c. R., NEWMAN, L. P., and AllanSmith, M. R. (1973) Amer. f. Ophthal., 76, 89 SCHWICK, H. G., and BECKER, W. (1969) Bayer Symposium I, 253

TOMASI, T., and BIENENSTOCK, J. (1968) Advanc. Immunol., 9, I 